\title{
Vinkel en koljander? \\ ‘n Diversiteitsperspektief op Afrikaanse en Nederlandse moedertaal-taalhandboeke
}

\section{A B S T R A C T Where human society is involved, the world can never be objective, but is a place where,} through cultural power relations, human inequalities are legitimized by meaning, interpretation and value (Hall 1997). At the same time prejudice and stereotyping disguise inequality and enhance the exclusion of certain sectors of society. Mechanisms such as inclusions, exclusions, confusing representations, cultural codes, and silences are relevant stereotyping strategies. In this article the visual representations in Dutch and Afrikaans language textbooks are compared in order to determine the strategies used to address diversity within the textbooks. The conceptual framework and literature review comprise an explication of the concepts and influential issues presented in the literature. Data sources are constituted by the visual material of one textbook series from each of the two language communities. The findings are presented as indicators derived from focus group discussions. Eurocentric perspectives of the dominant white group about the 'other' were identified, projecting the 'other' as problematic, poor and primitive. The cultural codes in the visual material furthermore generalise the non-Western 'other' as either extremely religious or as fundamentally different. No signs of apartheid prejudice could be found in the Afrikaans textbooks and Afrikaans is demythologised as a 'white' language. The visual material offers a platform for different, even contradictory, values in order to create a new cultural and social reality, even if the representation, in which everybody speaks Afrikaans, is sometimes forced and unauthentic.

Keywords: diversity, representational practices, visual material, language textbooks, Dutch and Afrikaans, stereotyping strategies, thematic analysis, focus group discussions

\section{Inleiding en vertrekpunt}

Daar is ' $\mathrm{n}$ groeiende besef onder leidende stemme in handboekondersoeke (Apple, 1990; Giroux, 1995; Marsden, 2001; Montgomery, 2005) dat kulturele waardes, kennismanipulering 
en amptelike perspektiewe onwillekeurig integreer tot 'n magspel wat veroordelende perspektiewe en ideologiese voorstellings in diens van die verskuilde of koverte kurrikulum 1 vertroetel. In handboeke manifesteer ras en kultuurvooroordeel as sosio-politieke konstruksies wat "prominensie aan sekere vorme van kennis verleen, terwyl dit ander verskuil of ignoreer" (Apple \& Christian-Smith, 1991:97, eie vertaling). Hierdie ondersoek gaan van die aanname uit dat die materiaal wat ondersoek word, nie arbitrêr is nie, maar deur die sosiale wêreld waarin dit gereproduseer word, geënkodeer word. Een veelgebruikte Nederlandse en een veelgebruikte Afrikaanse handboekreeks word deur fokusgroepbesprekings in Nederland en Suid-Afrika ondersoek om vas te stel in watter mate ideologiese voorstellings in diens van kennismanipulering aangewend word.

\section{Probleemstelling en navorsingsvraag}

Die verwantskap tussen die Afrikaanse en Nederlandse taalgemeenskappe bied 'n natuurlike navorsingvergelyking. Wat sou die invloed van die gemeenskaplike herkoms en kulturele waardes op die ideologiese voorstellingspraktyke van die twee gemeenskappe wees? 'n Ondersoek na die funksionering van 'dieselfde' taal in twee verskillende diversiteitskontekste, en die verskille en/ of ooreenkomste ten opsigte van onderliggende magswerking kan betekenisvolle inligting ten opsigte van die sosiologie van skoolkennis oplewer. Figuur 1 gee die relevansie van die studie sinopties weer:

FIGUUR 1: Die twee gemeenskaplike gemeenskappe

\section{TWEE GEMEENSKAPLIKE GEMEENSKAPPE}

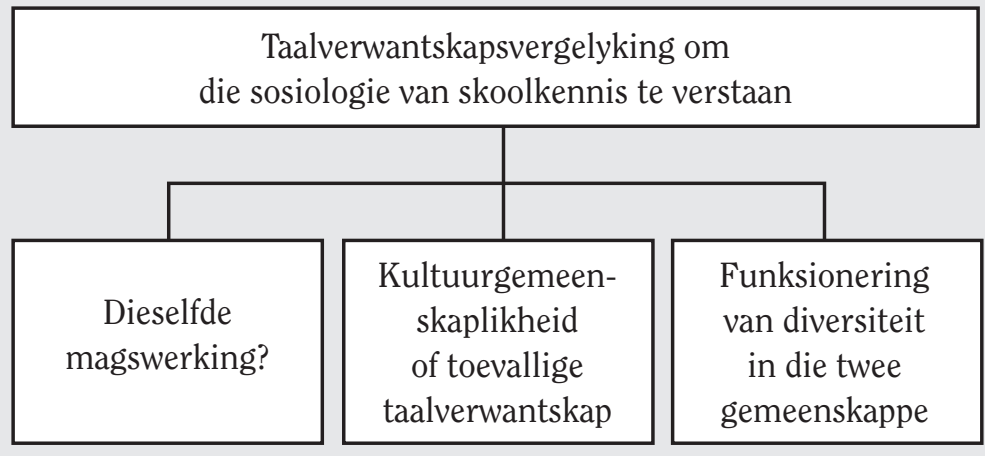

Die volgende navorsingsvraag sal die ondersoek rig: In watter mate verskil die diversiteitsperspektief in die visuele materiaal in taalhandboeke van verwante spraakgemeenskappe?

1 Apple (1990:84) definieer die verskuilde kurrikulum as "the norms and values that are implicitly, but effectively taught in schools and that are not usually talked about in teacher statements of end or goals" en voeg by: "... children learn to falsify certain aspects of their behaviour to conform to the reward system extant in most classrooms." 


\section{Kontekstualisering en konseptuele begronding}

\subsection{Nederland}

Islamitisering, immigrasie en diversiteit in Nederlandse skole het in die afgelope dekade brandende kwessies geword. Dit wil voorkom asof die multi-kulturele werklikhede waarvoor Nederland tans staan, die land (nou eers) met sy donker koloniale verlede konfronteer. In 1997 reeds skryf die kontroversiële politikus Pim Fortuyn ${ }^{2}$ oor die "islamisering van onze cultuur" (Botman, Jouwe, \& Wekker, 2001:11); in 2000 skryf Paul Scheffer, tot 2005 hoogleraar aan de Universiteit van Amsterdam en prominente lid van die Arbeidersparty, dat die huidige beleid te veel ruimte laat vir "migranten en vluchtelingen" (Botman et al., 2001:11) en kort daarna betoog die sosioloog Paul Schnabel dat Nederland geen multi-kulturele samelewing is nie en dit ook nie moet word nie (Botman et al., 2001). Schnabel, vanaf 2006 direkteur van die Nederlandse regering se Sociaal en Cultureel Planbureau, word in 2006 gelys as een van die top tien persone in Nederland (Paul Schnabel, 2009). Al drie meningvormers fokus op die verskil tussen 'ons' (wit) en 'hulle' (ander) Nederlanders.

Die verskillende benamings wat sedert 1970 aan Nederlanders van kleur gegee is, asook die chronologie daarvan, gaan van dieselfde polarisende vertrekpunt uit en bied 'n blik op die diversiteitsdenke in Nederland. Naamgewing, terminologieë en begrippe is affektief en kultureel gelaai en weerspieël historiese ontwikkelings wat in 'n sosiale magstruktuur ingebed is. (Hagendoorn, 1986; Nele, 1996; Shadid, 1994).

Die aanvanklike gasarbeiders uit Suid-Europa, Turkye, Noord-Afrika en Nieuw-Guinee ${ }^{\mathbf{3}}$, sou na hulle eie lande terugkeer ná hulle voorsien het in die tekort in die arbeidsmark (Botman et al., 2001). In die 1980's word die term 'gasarbeiders' deur 'migranten' vervang, 'n term met twee konnotasies, te wete iemand wat heen-en-weer beweeg tussen verskillende lande en ' $\mathrm{n}$ niewettige (im)migrant. 'n Nuwe term, 'asielzoekers', het ontstaan toe vlugtelinge in die 1980's om Nederlandse paspoorte aansoek doen. Teen die einde van die tagtigerjare was dit duidelik dat nòg die 'asielsoekers' nòg die 'migrante' weer na hul eie lande teruggaan. 'Minderhede' is ingestel as die nuwe amptelike term. Hagendoorn (1986) kritiseer hierdie term, omdat dit op "n sosiale groepering met weinig mag dui. Die kwantitatiewe term kry 'n kwalitatiewe assosiasie van onwaardig en ongelykwaardig. Ook kry die term in die maatskaplike sin 'n stereotipiese betekenis. Dit roep assosiasies met agterstand en probleme 'n maatskaplik agtergestelde posisie en gebrek aan institusionele mag op. In 1989 word 'minderhede' met die sambreelterm 'allochtonen' vervang. 'Allochtoon' sluit die volgende groeperings in: gasarbeiders, mense uit voormalige kolonies en mense van wie minstens een van die ouers nie in Nederland gebore is nie (Allochtoon Sa.).Twee teenstrydighede spreek uit hierdie naamgewing. Eeerstens word alle etniese minderhede volgens (Botman et al., 2001:159) op "een grote hoop gegooid":

2 "Pim Fortuyn was the centre of controversy for his views on Islam and his anti-immigration positions. He called Islam "a backward culture" and said that he would close the borders to Muslims if it were legally possible" (Pim Fortuyn 2009).

3 Die eerste groep Nieuw-Guinee-Molukkers is in 1951 na Nederland gebring. In 1962 is die Nederlandse deel van Nieuw-Guinea aan Indonesië oorhandig, maar Molukkers wat vir die Nederlandse bestuur gewerk het, het die opsie gehad om na Nederland te gaan, waar hulle dan Nederlandse burgerskap sou verkry (Molukkers naar Nederland Sa.). 
De terminologie 'allochtoon' schijnt voor ons migranten, vreemdelingen, zwarten, asielzoekers, vluchtelingen, zigeuners, burgers van EEG-lidstaten een verzamelnaam te zijn zolang alles maar controleerbaar blijft en rust en harmonie heerst in dit landje.

Tweedens definieer die Nederlandse regering se Centrale Buro vir Statistiek (CBS) die begrip 'allochtoon' deur te onderskei tussen eerste en tweede generasie 'allochtonen'. Eersgenoemde verwys na ' $n$ persoon wat in Nederland woon, maar elders gebore is en van wie ten minste een ouer ook in 'n ander land gebore is. Laasgenoemde verwys weer na "n Nederlander van wie minstens een ouer in 'n ander land gebore is. " $n$ Nederlander van wie een ouer byvoorbeeld in Vlaandere gebore is, behoort, volgens hierdie definisie, dus 'allochtoon' te wees. Die algemeenaanvaarde omgangstaal wyk egter heeltemal hiervan af. Iemand is slegs 'allochtoon' wanneer hy/ sy ten opsigte van voorkoms en gedrag duidelik van wit Nederlanders verskil (Allochtoon, Sa.).

Die term 'allochtoon' sluit dus witmense uit. 'n (Wit) Poolse of Suid-Afrikaanse immigrant sal nie 'allochtoon' wees nie, al is nie een van die ouers in Nederland gebore nie; maar ' $\mathrm{n}$ swart Pool of Suid-Afrikaner sou wel 'allochtoon' wees (Wekker, 2006). Dit is ook die geval met die chronologie van die name tot dusver bespreek: 'gasarbeider', 'asielsoeker', 'migrant', 'minderheden'- almal het een kenmerk gemeen: hulle is nie-wit. Ook die nuutste toevoeging tot hierdie naamgewingsproses, 'nieuwkomers' verwys amptelik na "mensen boven de achttien jaar, die minder dan een jaar geleden in Nederland zijn gekomen”, maar daar word selde indien ooit, na witmense as 'nieuwkomers' verwys (Botman et al. 2001:159).

Wanneer etniese groeperinge as probleemmense gesien word, soos in Nederland (De Figueiredo \& Elkins, 2003; Perkins, 2003; Smelink, 1999), vind stereotipering plaas, omdat veralgemeen word en omdat 'probleem' 'n negatiewe assosiasie het. Terselfdertyd is dit eufemisties omdat dit nie openlik vyandig is nie. Westerse lande se vrees vir vreemdelinge berus op implisiete stereotipering (Ledic, 2000; Nganda, 1996). Hoe sterker die xenofobie, hoe sterker die implisiete stereotipering waarvolgens 'hulle' andersheid 'ons' eendersheid bedreig (De Figueiredo \& Elkins 2003). Die persepsie dat daar geen raakpunte tussen 'ons' en 'hulle' is nie, vorm dus die basis van nie alleen die affektief-gelaaide naamgewing nie, maar ook die polarisering en xenofobie waarna verwys is.

\subsection{Suid-Afrika}

Die nuwe, demokratiese Suid-Afrika bestaan reeds sedert 1995. Dit is dus noodsaaklik en tydig om in retrospek te kyk na hoe suksesvol Afrikaanse handboeke in die omkering van die vorige bedeling se oningeligte en met vooroordeel-gevulde voorstellingspraktyke was (Esterhuyse, 1986; Webb, 1992). Is die ignorering en stilswye ten opsigte van die religieuse en die sosiolinguistiese werklikhede van die Afrikaanssprekende taalgemeenskap reggestel? Die helfte van die Afrikaanse gemeenskap is immers bruinmense (Esterhuyse, 1986). "n Moedertaaltaalhandboek behoort die wêreld van alle moedertaalsprekers van die taal te weerspieël, tog is Afrikaans gedurende apartheid as die alleenbesit van die blanke Afrikaner geprojekteer (Engelbrecht, 2003).

'n Opspraakwekkende studie tydens apartheid was 'n sosiolinguistiese ondersoek: Taalhandboeke binne die Christelik-Nasionale apartheidsparadigma (Esterhuyse, 1986), wat ontstellende taalstereotipering ten opsigte van bruin Afrikaanssprekendes in twee 
veelgebruikte handboekreekse, naamlik Afrikaans my taal en Ons moedertaal uitgewys het. Taalstereotipering begin, volgens hierdie studie, by die implementering van Algemeen Beskaafde Afrikaans ('n term wat setel in die koloniale geloof dat die blanke die beskawing na Suid-Afrika gebring het). Die waarde van Esterhuyse (1986) se ondersoek lê enersyds daarin dat Afrikanereksklusiwiteit aan die hand van universele sosiolinguïstiese reëls aan die kaak gestel is. Sosiolinguistiese manipulasie deur sillabusbeplanners, voorskryfkomitees en handboekskrywers kom byvoorbeeld in die studie onder skoot. Andersins het die ondersoek openbaar in watter mate bruin Afrikaanssprekendes in die 20 ste eeu geïgnoreer en gestigmatiseer is. Hierdie taalstereotipering het by die bruin sprekers van die Kaapse variant ' $n$ identiteitskrisis laat ontstaan, wat uiteindelik 'n grootskaalse taalverskuiwing na Engels meegebring het (Engelbrecht, 2003). In watter mate is die bordjies na meer as ' $n$ dekade van demokratisering verhang? Is daar byvoorbeeld steeds Eurosentriese reste in die boeke teenwoordig?

In watter mate word sensitiewe kwessies (veral rondom politiek en godsdiens) wel aangespreek? In Suid-Afrika is regeringsbetrokkenheid, bepaalde seleksieprosedures en die aanbeveling van bepaalde voorgeskrewe handboeke algemene praktyk. Daar was sedert 1994 ook doelbewuste beleidsinisiatiewe om gelykheid en regverdigheid in leermateriaal te verseker. McKinney (2005:1) verduidelik:

... the setting up of the Race and Values Directorate in the National Department of Education (DoE), the establishment of a special sub-committee on human rights to ensure the integration of values into the revised national curriculum ... and the creation of of anti-racism and human rights in education networks by the South African Human Rights Commission (SAHRC) ...

Hoe eerlik en outentiek is de-stereotiperingstegnieke en -strategieë? In 'n studie oor geskiedenishandboeke in Suid-Afrika na 1995 (Engelbrecht, 2008), word byvoorbeeld bevind dat kitsstrategieë soos swart/wit rolomkering of te wel 'exchanging white heroes for black heroes' (Jansen, 1989), aangewend word om apartheidsvoorstellings van die verlede reg te stel. Montgomery (2005) argumenteer dat handboeke in Kanada, die beeld van 'n anti-rassistiese en onproblematiese staat konstrueer (in teenstelling met die Kanadese werklikheid),. Is dit moontlik dat Afrikaanse handboeke ter wille van konformering aan 'politiese korrektheid' en goedkeuring deur departementele komitees dieselfde doen? Kusendila (2003) beweer byvoorbeeld dat ' $n$ ideale prentjie van hoe ' $n$ gemeenskap behoort te funksioneer in die handboekreeks Raamwerk gekonstrueer word, asook dat ander tale en hul sprekers nie werklik in die reeks 'n stem kry nie, aangesien almal (swart of wit) voorgestel word asof hulle vanuit huis Afrikaanssprekend is.

Die nuwe demokratiese post-apartheid waardes en norme behoort dus in die nuutste leermiddele te manifesteer, maar in watter mate dit kunsmatig is of ter wille van die goedkeuring deur die provinsiale onderwysdepartemente verander is, bly ' $\mathrm{n}$ ope vraag.

\section{Literatuurstudie}

Internasionale navorsingstemas ten opsigte van handboeke het gedurende die afgelope dekades 'n verwikkelde ontwikkelingspatroon getoon. Voor die Eerste Wêreldoorlog was navorsingstemas toegespits op post-koloniale invloede, gedrewe deur ' $n$ beskawingsmissie wat 
by implikasie enige produktiwiteit in ontwikkelende lande misken het (Greaney, 2004). Naoorlogse studies het probeer lig werp op die impak van verdraaide historiese feite, uitbeeldings van minderwaardigheid en politieke vooroordele op die onderwyssisteme van verskillende lande, gemeenskappe en rasminderhede. 'Onderliggende aannames' en 'verskuilde agendas' was die akademiese jargon van die afgelope drie dekades. Kwantitatiewe inhoudsanalises het gelyke voorstellings van ras, geslag, klas en gestremdheid in tekste en illustratiewe materiaal bereken, wat op grond van die letterlike en simboliese betekenisse wat hieraan geheg kon word, gekategoriseer is (McDiarmid \& Pratt, 1971; Paton \& Deverill, 1974; Stewart, 1950).

Vergelykende ondersoeke oor ooreenkomste en verskille tussen die handboeke van die sogenaamde 'ontwikkelde' en 'ontwikkelende' lande wat eers in die middel 1980's begin het, was uitsluitlik toegespits op die probleme van ontwikkelende lande, naamlik armoede, wanvoeding en hongersnood (De Jongh, 1995; King \& Morrisey, 1988; Nele, 1996; Van den Berg \& Reinsch, 1983) In Suid-Afrika verskyn die eerste studie oor rasvooroordeel in SuidAfrikaanse handboeke reeds in 1965, te wete die opspraakwekkende studie van Auerbach, wat later as motivering gedien het vir die Educational, Scientific and Cultural Organisation (UNESCO)-verslag History in black and white (Dean, Hartmann \& Katzen, 1983).

In die afgelope twee dekades het die navorsingsmetodes verander van positivistiese ontledings van negatiewe beelde wat in diens staan van óf 'ons' óf 'hulle' tot konstruktivistiese pogings om wetenskaplike kennis te ontwikkel oor hoe stereotiperende voorstellings en blote assimilerende werkswyses effektief teëgewerk kan word (McKinney, 2005; Rice, 2005). Kontemporêre ondersoeke is merendeels kwalitatief van aard en word gekenmerk deur interaksie tussen verskillende antropologieë en sisteme. Klem word dus geplaas op nuwe en verskillende stemme wat in hierdie ondersoekveld te voorskyn kom en wat hierdie stemme ten opsigte van bepaalde sosiale en politieke wêreldbeelde weerspieël (Montgomery, 2005; Roberts-Schweitzer, 2006; Sierens, 2000).

Nie alleen is hierdie nuwe navorsingsfokus reeds in 1990 deur akademiese afgevaardigdes na die George Eckhardt Institute (GEI) for Textbook Research ${ }^{4}$-werkswinkel in Braunschweig, Duitsland, bevestig nie, maar die navorsingstemas in die handboek-ondersoekveld is ook tydens hierdie navorsingswerkswinkel ' $\mathrm{n}$ stap verder gevoer. Konsensus is bereik dat toekomstige navorsing oor handboeke van die veronderstelling moet uitgaan dat kontroversiële kwessies wat voorheen gerieflikheidshalwe omseil of geïgnoreer is, aangespreek behoort te word (Bourdillon, 1992). Wat nie verander het nie, is die amper onaantasbare rol van handboeke in die konstruksie van sosio-politiese paradigmas waarbinne leerders se sosialisering plaasvind; asook die inherente regverdiging wat handboeke aan kulturele norme verleen (Apple \& Christian-Smith, 1991; McKinney, 2005; Mok \& Reinsch, 1996). Handboeke word dus steeds beskou as sosio-kulturele 'agente' wat as voedingstof vir formele en verskuilde kurrikula dien. Evaluerende studies wat kennis aangaande onbewustelike persepsies, waardes en stereotipes

4 Hierdie instituut, gestig in 1951, publiseer studies oor die inhoud van nasionale, Europese en globale geskiedenis in skoolhandboeke. Internasionale seminare oor handboekanalise word ook aangebied, byvoorbeeld die Baltic States History Textbooks Project wat op die gemeenskaplike interpretasie en insig ten opsigte van historiese gebeure in Estland, Letland en Litaue gemik is. Uiteindelik is een handboek met al die betrokke lande se historiese perspektiewe ten opsigte van die Baltiese streek uitgegee (Stradling, 2001). 
ontwikkel, poog om alle leerders se sosiale werklikhede op grond van die herkennings- en identifiseringsbeginsel wat in handboeke behoort voor te kom, te weerspieël (Homan, 2003; Höpken, 2006; McKinney, 2005). Die demitologisering van persepsies aangaande ontwikkelende lande word (volgens Kaomea, 2000 en McCall, 2005) steeds deur Eurosentriese perspektiewe in die wiele gery.

Dit is duidelik dat daar nie in die handboekwêreld "n "bibliotopia" 5 bestaan nie. Tradisionele rassisme, diskriminasie, etikettering en growwe veralgemenings kom baie minder voor as in die verlede, maar terselfdertyd is daar voortdurend nuwe mutasies en manifestasies van etnosentrisme, wat die ondersoek na stereotipiese voorstellings kompliseer (Paton \& Deverell, 1974; Rice, 2005; Mok \& Reinsch, 1996). Ignorering of omseiling is die algemeenste vorm van implisiete stereotipering. Dit neem verskeie vorme aan: nie al die feite word gegee nie; die buitegroep se bydrae word verklein; die binnegroep alleen word uitgebeeld as verantwoordelik vir positiewe ontwikkeling en negatiewe, eerder as positiewe menings, word aangaande die buitegroep gegee (Kirkness 1997; Roberts-Schweitzer, 2006).

Daar is tans ' $n$ vakuum in die literatuur ten opsigte van moedertaal-taalhandboeke asook die vergelyking van stereotipering in die handboeke van verwante taalgemeenskappe. Slegs een studie vergelyk moedertaal-taalhandboeke en wel ten opsigte van die vergestalting van identiteit in Afrikaanse en Vlaamse handboeke (Kusendila, 2003).

\section{Data-insameling}

Akademici is dit eens dat fokusgroepbesprekings 'n ryk beskrywing van kommunikasie oor 'n gestelde verskynsel moontlik maak. Idees kan opgevolg word en reaksies, motiewe en emosies kan grondig ondersoek word - aspekte wat 'n vraelys byvoorbeeld nie doen nie (Creswell, 1994; Mouton, 2001). Volgens Babbie en Mouton (2001:292) skep fokusgroepbesprekings 'n ruimte waarbinne betekenis tussen groeplede onderhandel word, eerder as om te volstaan by individuele betekenisskepping. Vir outsider-navorsers is betekenis-onderhandeling waartydens fokusgroeplede verbande tussen hul eie leefwêrelde en die handboeke in hulle eie gemeenskappe trek, van onskatbare waarde.

Die fokusgroepbesprekings het onderskeidelik op 12 April 2007 en op 12 November 2008 by die Universiteit Utrecht (Nederland) en die Universiteit Pretoria plaasgevind. Kollegas verbonde aan beide inrigtings het as fasiliteerders opgetree, terwyl ek as navorser deurgaans teenwoordig was. Die fokusgroepbesprekings het ongeveer twee ure elk geduur en is opgeneem en getranskribeer. Die fasiliteerders is volledig en skriftelik ten opsigte van die modus operandi ingelig en is van die nodige apparatuur voorsien om in die fokusgroepbesprekings met die gekodeerde illustrasies te werk.

\section{Bevindinge}

\subsection{Verslag van die fokusgroepbespreking in Nederland oor Nieuw Nederlands (NN)}

\subsubsection{Algemene indrukke}

5 James McCall van The Centre for Publishing Studies University of Stirling, gebruik hierdie term in September 2005 tydens ' $n$ aanbieding by die Universiteit Pretoria. 
Ten opsigte van die voorblad van Nieuw Nederlands was die fokusgroeplede dit eens dat dit 'n positiewe beeld van Nederland as diversiteitsland gee. Deelnemer 1 sê:

De titel van het boek Nieuw Nederlands wijst op de 'nieuwe' Nederlanders. Het zijn niet meer alleen blonde, blauw-ogige Nederlanders. De jongen lijkt Mediterraans of Turks. Dat is stereotyperend-ontkennend, omdat er 'iets van allemaal' in zit.

Die titel van die boek (Nieuw Nederlands) impliseer ook dinamiese verandering in die sin van Nederlands wat 'nuut' dink en kyk. Die fokusgroeplede het hulle egter van meet af aan in die algemeen sterk teen die gebruik van die visuele materiaal in die handboek uitgespreek. Die algemene probleme wat hulle ten opsigte van die handboek geopper het, gestaaf deur aanhalings uit die fokusgroepbespreking, word nou verskaf:

Geen byskrifte, vrae of opdragte verhelder die gebruik van die foto's nie. Deelnemer 1 beskryf hierdie verskynsel as 'heel irritant.'

Die assosiasies tussen die foto's en die geskrewe tekste is in feitlik al die gevalle onduidelik. Deelnemer 2 reageer soos volg ten opsigte van Nieuw Nederlands 5/6:47:

Mense die in de rij staan en op de bus wachten ... wat dit met dat artikel te maken heeft, dat over de Verlichting gaat, weet ik echt niet.

Afgesien van die feit dat die verband onduidelik is, is dit dikwels ' $n$ valse voorstelling van wat in die teks voorkom:

Iemand die leest... in een stuk over analfabeten... (Deelnemer 3 ten opsigte van Nieuw Nederlands 5:90).

Die politieke lading in sommige foto's is onvanpas. Deelnemer 2 verwys soos volg na Nieuw Nederlands 5/6:228: Wat mij onmiddellijk opvalt, is het plaatjie om de hals. Een Arabisch sjaaltje met een politieke kleur... Dome of the Rock. Jeruzalem, politieke lading, niet verstandig in schoolboeken.

Die foto's lyk afkomstig vanuit ander lande en min daarvan verbeeld die tipiese Nederlandse werklikheid. Deelnemer 2 sê dat die foto's "samengesteld zijn door iemand die over de hele wereld gereisd heeft."

Wanneer 'n boek inhoudelik slaag (Nieuw Nederlands is 'n veelgebruikte boek in Nederland), is dit nie noodwendig geslaagd ten opsigte van diversiteit nie.

Deelnemer 1: Is het wel verstandig is om een boek volgens multiculturaliteit goed te keuren wijl de inhoud bijvoorbeeld slecht is?

Deelnemer 2: Is het boek dan zogenaamd goedgekeurd?

Die temas wat uit die fokusgroepbespreking gekristalliseer het, word vervolgens bespreek.

\subsubsection{Anders-as-'ons'}

Die fokusgroeplede beskryf sommige van die uitbeeldings as karikatuuragtig, ander as ekstremisties, maar definitief as anders-as-Westers. Met betrekking tot Nieuw Nederlands 5/6:187 wat verskillende karikature in (waarskynlik) 'n dokter se spreekkamer toon, beweer Deelnemer 4 dat die uitbeelding van die tradisionele swartman stereotiperingbevestigend is, aangesien hy heeltemal anders as die ander karikature (almal Westers) sit. In Nieuw Nederlands 
5/6:228 (die gesprek tussen twee Moslemvroue en ' $\mathrm{n}$ Westerling) word die foto, volgens Deelnemer 2, onmiddellik polities gekleur deur die teken van ekstremisme op die sjaal van een van die vroue, wat op 'n ekstremistiese groep wat hulle beywer vir die bevryding van Jerusalem, dui. Ook die foto van die tradisioneel geklede (Tibetaanse?) seuns op die trappe van wat blyk 'n religieuse tempel te wees (Nieuw Nederlands, 4:90), beklemtoon dat hulle 'anders-as-ons' is, of soos Deelnemer 1 dit stel: "dat zijn niet general society; modern versus traditioneel." Die foto van die groep Sjinese mans (Nieuw Nederlands, 4:13) is ook ekstremisties, vreemd en onverklaarbaar. Deelnemer 4 meld dat nie-Europeërs wat lees (Nieuw Nederlands, 5/6:47), gesien moet word in die lig van die feit dat die verligting geheel en al Europees was. 'n Foto van 'n lesende 'nie-Europeër' by 'n leesstuk oor die Europese verligting, impliseer op Eurosentriese wyse dat 'ons' verligting selfs by 'hulle' uitgekom het.

Nieuw Nederlands 5/6:228 beeld 'n gesprek tussen 'n Westerse en twee nie-Westerse vroue uit. Die ouer vrou lyk soos "n tipiese Westerse vrou ("zoals mijn oma" sê Deelnemer 4) wat iets "maatskaplijks" (Deelnemer 3) met die ander vroue bespreek en "heel geïnteresseerd lijken" (Deelnemer 1) in wat die ander vroue te sê het. Deelnemer 4 lewer kommentaar op die mate waarin die Westerse vrou deur die twee ander vroue ingesluit word:

Interessante foto. Als de twee vrouwen modern aangekleed waren, zou deze foto volgens mensen uit het Weste niet zo interessant zijn. Modern tegenover traditioneel, jonk tegenover oud. Als een jongere vrouw in de midden had gezeten, dan waren de drie vrouwen vriendinnen...

Die advertensie van die Nederlandse onderwysdepartement (Nieuw Nederlands, 4:27) skep 'n uiters positiewe beeld van 'ons' wat 'hulle' help. Die fokusgroepfasiliteerder lewer kommentaar op die komposisie van die foto: het is een stereotypering van een vlotte blanke jongen. De compositie is paternalistisch. Het ist een geënsceneerde foto; een aktiefoto zou beter zijn.

6.1.3 Probleme, primitiwiteit en armoede

' $\mathrm{n}$ Volgende tema is die van agterlikheid en onderontwikkeldheid. Visuele voorstellings in Nieuw Nederlands, 5/6:17, Nieuw Nederlands, 4:146 en Nieuw Nederlands, 5/6:167 is uitbeeldings van primitiwiteit, probleme, en armoede. Deelnemer 4 beskryf die implisiete boodskap van die visuele voorstelling in Nieuw Nederlands, 4:146 soos volg:

Ook in heel kleine dorpjes in de townships in Afrika, hebben mensen mobieltjes. Dat is dus niet gebaseerd op de waarheid. Het is de uitbeelding van de achterlijke cultuur van mensen die ver van ons wonen.

Deelnemer 1 voeg hierby:

Stereotyperingbevestigend... achterlijke, onderontwikkelde Afrikaan die ons wil nadoen met zijn telefoontje dat niet echt is. Ik doe alsof ik een mobieltje heb. Zo iets van: je kan het wel nadoen, maar je hebt het niet. Zo'n zielig Afrikaansachtig beeld van 'daar zijn jullie allemaal zo'.

Visuele voorstellings Nieuw Nederlands, 5/6:17 en Nieuw Nederlands, 5/6:167 suggereer dat die jong vrou en die kinders "kansarm" is (Deelnemer 2); dat hulle onderwys primitief is (Deelnemer 1); dat die jong vrou waarskynlik eers op "n laat stadium in haar lewe die kans kry om te leer lees en skryf (Deelnemer 2) en dat hierdie geleentheid hom as gevolg 
van ontwikkelingshulpgeld vanuit die Weste voordoen (Deelnemer 4). Die vraag word gevra waarom die foto van die kinders wat ingedruk langs mekaar op die grond sit, by 'n leesstuk geplaas word wat oor geboortebeperking in China handel. Die enigste antwoord waarmee die groep vorendag kan kom, is dat die foto (ook) op oorbevolking dui:

Het traditionele beeld van overbevolking suggereert heel veel bij elkaar. Het duidt op Afrikanen die geboortebeperking moeten toepassen. Men kon toch veel beter een Chinees gezin tonen dat alleen maar twee kinderen heeft.

\subsubsection{Samevatting}

Die fokusgroeplede is dit eens dat die visuele voorstellings in Nieuw Nederlands nie die werklikheid van 'n diverse Nederland weerspieël nie en dat die foto's wat wel van anders-as-wit mense geneem is, waarskynlik op enkele uitsonderings na, buite die grense van Nederland geneem is. Die feit dat diversiteit steeds as 'n probleem beskou word, blyk uit die 'kansarme' indruk wat deur die meerderheid foto's gesuggereer word.

\subsection{Verslag van die fokusgroepbespreking oor Afrikaans ons taal (AOT)}

\subsubsection{Algemene indrukke}

Aanvanklik het die bespreking gesukkel om aan die gang te kom; die deelnemers het nie by die opdrag om stereotipering, veral implisiete stereotipering, aan te dui, uitgekom nie. Lang besprekings is gehou oor naamgewing in Afrikaans, sonder om by die essensie uit te kom, naamlik hoe naamgewing as tegniek gebruik kan word ter wille van in- of uitsluiting.

Anders as by die Nederlandse fokusgroepbespreking was daar in die fokusgroepbespreking onderliggende rassensitiwiteit. Eerstens was daar spanning rondom terminologie. Deelnemer 2 gebruik die term 'swart' en Deelnemer 7 reageer met 'n opmerking dat ' $n$ bepaalde karakter 'bruin' en nie 'swart' is nie, waarop Deelnemer 2 antwoord dat sy die term generies gebruik het. Die spanning is daarin geleë dat bruinmense hulself uit solidariteit met swartmense tydens apartheid van die term 'bruin' gedistansieer het en na almal wat nie-wit is nie, verwys het as 'swart' (Esterhuyse, 1986).

Deelnemer 7: ... maar sy's nie swart nie.

Deelnemer 2: I use black generically.

Deelnemer 7: You're not going to get a coloured girl called Lethabo.

Tweedens het Deelnemer 1 die geldigheid van hierdie studie bevraagteken deur na die handboekkrisis in Suid-Afrika te verwys, wat tot gevolg het dat slegs ongeveer 'n derde van die leerders in Suid-Afrika wel handboeke het (Radio Sonder Grense-nuus, 2006): Is the study about the assumption ... is the assumption of the study that the schools are using textbooks?

Hierdie opmerking het 'n nuanse aan die fokusgroepbespreking gegee van 'julle hou julle besig met boeke vir die bevoorregte, eksklusiewe deel van die bevolking (net soos julle in die verlede gedoen het).

Derdens het een van die fokusgroeplede direk na afloop van die fokusgroepbespreking in ' $n$ e-pos gebieg dat sy nie onvoorwaardelik haar eie interpretasie gegee het nie, maar haar woorde 
deurgaans geweeg het, sodat dit nie onsensitief ten opsigte van die 'ander' voorkom nie: Ek was half geskok in my eie reaksie. Ek was definitief geïnhibeer en het nie gesê wat ek normaalweg sou nie. Ek was bang dat as ek my mening gee, dit dalk as onsensitief teenoor hulle sou oorkom. Ek was heeltyd daarop bedag om te formuleer en te benoem sodat hulle nie voel dat ek kleur raaksien nie.

Vierdens het een van die wit fokusgroeplede dit vreemd gevind dat daar soveel 'politieke' inhoude in 'n taalboek voorkom, waarop Deelnemer 1 gereageer het met die vraag waarom hy die illustrasies (wat oor menseregte handel) as polities beskou (Afrikaans ons taal, 11/12:52 en Afrikaans ons taal, 11/12:653). Volgens Deelnemer 1 is inligting oor maatskaplike opbou en humanitêre beginsels natuurlike en noodsaaklike pilare van 'n demokratiese staat en het dit niks met politiek te make nie. Hierdie opmerking het gesuggereer dat witmense menseregtekwessies as polities sien, omdat daar in die verlede so lank geen aandag aan menseregte gegee is nie. Die suggestie word deur Deelnemer 2 ondersteun, wat byvoeg dat sodanige siening (dat menseregte 'polities' is), nét in Suid-Afrika voorkom.

\subsubsection{Aard van die visuele materiaal}

Die fokusgroeplede het wel die gebruik van die butterscotch-tegniek in die tekste (Afrikaans ons taal, 10:6 en Afrikaans ons taal, 10:28) bespreek en konsensus bereik dat die butterscotchtegniek kleur op 'n positiewe manier verdoesel.

Deelnemer 7: Ek persoonlik lees glad nie kleur in die prentjie nie. Party is ingekleur, ander nie. Hulle is vir my dieselfde.

Deelnemer 5: Ek dink dit is miskien waardevol, want dit is dalk wat hulle probeer bereik; juis om hom nie uit te sonder nie, ek ervaar nie enigiets negatiefs nie.

Die groep spreek hulle by meer as een geleentheid sterk teen die groot persentasie illustrasies teenoor die klein persentasie foto's uit. Kort-kort verwys iemand na die feit dat illustrasies nie so realisties soos foto's is nie, byvoorbeeld die visuele voorstelling in Afrikaans ons taal, 10:28 en dat die verskeidenheid illustrasiestyle irriterend is. Ten opsigte van die visuele voorstelling in Afrikaans ons taal, 11/12:62 is almal egter positief:

Deelnemer 5: Kyknou net hoe baie sê hierdie skets. Kykwat sien jy in hierdie tekening, veral in die volgende gesig. Dis vir my amper meer waardevol as wat 'n foto sou wees. Ek sien die ö̈, ek sien amper die gedagtes in die ö̈.

Deelnemer 6: Dis amper 'n kunswerk.

Deelnemer 2: I think ... for me it's diverse. I see diversity because maybe he's Afrikaans (wit), maybe he's black.

Die groepslede kom uiteindelik tot die gevolgtrekking dat die illustrasies generiese karakters skep sodat mense makliker daarmee kan identifiseer, asook dat mense op " $\mathrm{n}$ baie meer subjektiewe manier na illustrasies as na foto's kyk. Die uitbeelding van die emosies van verskillende kultuurgroepe word, volgens die fokusgroeplede, positief en empaties in Afrikaans ons taal, 11/12:186 gedoen. Deelnemer 5 praat byvoorbeeld van die "dierbare Griekwa-tannie" en Deelnemer 1 wys daarop dat die collage verskillende emosies suksesvol uitdruk en dat die kyker se emosionele respons nie deur die keuse van 'n bepaalde kultuurgroep geraak word nie. 


\subsubsection{Outentisiteit van die voorstellings}

Daar word onderling verskil oor die outentiekheid van enkele voorstellings. Lethabo (Afrikaans ons taal, 11/12:190), die "suksesvolle, passievolle en intelligente" (Deelnemer 5) werker van die versekeringsmaatskappy Outsurance, word bespreek. Alhoewel almal saamstem dat sy soos "n aangename mens lyk, sien Deelnemer 3 en 4 haar uitbeelding as enkelma met vier kinders as moontlike bevestiging van die stereotipering van 'disfunksionele' swart gesinne. Deelnemer 5 dink weer dat dit impliseer dat 'n enkelma ook as beroepsvrou suksesvol kan wees en dat dit die stereotipe van die 'perfekte gesin' deurbreek, omdat daar met verskillende gesinsmanifestasies rekening gehou word:

... die vreeslike handsome pa en die vreeslike sexy ma en die dierbare blonde dogterjie en die aktiewe seuntjie ... en hulle is nou so happy. En dis irrelevant, want jy kan dit nie gebruik nie, want dis nie hoe dit [die perfekte gesin] vandag lyk nie. So, dit is dalk net 'n subtiele manier om dit aan te spreek.

Die groep bespreek nog drie voorbeelde wat, volgens hulle, nie outentiek is nie. Eerstens beskou Deelnemer 1 Lethabo se taalgebruik as kunsmatig:

I was looking at the use of language, and the direct translation of sentences and whether Lethabo would speak like that. I would find it extremely difficult if she speaks like that unless it was translated from English to Afrikaans, and it's given a particular meaning. But I wouldn't see Lethabo speaking like that.

Hierdie siening stem ooreen met Kusendila (2003) se bewering dat 'n wêreld in Afrikaanse handboeke gekonstrueer word waarin 'alle mense Afrikaans praat'.

Tweedens wys hulle die 'fout' in Afrikaans ons taal, 10:15 uit. Die leesstuk vertel die verhaal van mevrou Van der Merwe ('n tipiese 'wit' vrou met 'n tipiese 'wit' van) wat 'n slang op haar rusbank ontdek, maar in die illustrasie lyk mevrou Van der Merwe soos die swart huishulp. Dit lyk asof die illustrasie doelbewus deur 'n 'swart' gesig vervang is. Deelnemer 6 voeg by dat "the idea is forced; the issue is forced."

Derdens voel die groep dat daar ten opsigte van sport en vermaaklikheid verteenwoordigende uitbeeldings oor die kultuurspektrum voorkom (byvoorbeeld in Afrikaans ons taal, 11/12:24 en Afrikaans ons taal, 11/12:193). Deelnemer 5 noem dat die visuele voorstelling van Afrikaans ons taal, 11/12: 91 in die eerste en laaste uitgawes van die boek verskil. Daar is dus doelbewus in die laaste uitgawe " $n$ swart sportvrou in die collage ingesit. Deelnemer 1 vra waarom dit nie "n Suid-Afrikaanse sportvrou is nie en insinueer dat geforseerdheid ook hier voorkom: It could have a negative effect. You can't get black people who are successful in sport. You have to go American.

\subsubsection{Afrikaanse taalvariasie}

Die groep lewer kommentaar op die verskeidenheid voorbeelde van Afrikaanse variëteite wat in die handboek aangetref word. Daar is heelwat dialoogvoorbeelde van byvoorbeeld Kaaps (Afrikaans ons taal, 11/12:79), Griekwa-Afrikaans (Afrikaans ons taal, 11/12:79) en Noord-Kaaps (Afrikaans ons taal, 11/12:80) asook letterkundige tekste in veral Kaaps, byvoorbeeld gedigte deur die digter Adam Small geskryf. Deelnemer 5 beskou dit as pogings tot herkenbaarheid vir alle Afrikaanse sprekers. Deelnemer 1 het egter ' $n$ voorbehoud ten opsigte van die variasie: 
If you see white people speaking just one kind of Afrikaans, whilst you portray other people speaking different types of Afrikaans... I would like to see that in the book; do they do that? Do they conveniently see white people as one, above all other people? If white people don't speak the same type of Afrikaans ... if the author is doing that...

Deelnemer 1 se voorbehoud is dus dat variëteite nie altyd net as "nie-wit" uitgebeeld moet word nie, omdat dit stigmatiserend kan wees, terwyl witmense almal net "op een manier" praat (Esterhuyse, 1986). Die groep kyk dan na "n voorbeeld van waar twee witmense NoordKaaps praat (Afrikaans ons taal, 11/12:80) wat Deelnemer 1 se voorbehoud ophef. Die gedig deur Boerneef, "Geelkeelkanarie" (Afrikaans ons taal, 11/12:6), wat geillustreer word deur "n moderne jong swart sangeres, deurbreek ook taalstereotipering.

Die gesprek oor taalvariasie het op " $n$ natuurlike wyse oorgegaan in 'n bespreking oor die verpolitisering van Afrikaans. Deelnemer 7 haal weer die kwessie van 'te veel politiek in ' $n$ taalhandboek' op:

Wat vir my belangrik is, wat positief is, is dat ek lank gedink het my Afrikaans is die enigte regte Afrikaans wat ons s'n is, dit word hier goed teëgespreek...Daar is variëteite en almal is aanvaarbaar, maar dan, weer eens: as dit ' $n$ taalkundeboek is, is dit dan nie bietjie te veel nie? Is dit nodig dat dit polities is? Dis die vraag wat ek vra, want is dit die doel van die boek?

Hierdie uitspraak lok hewige debatvoering uit. Deelnemer 5 is van mening dat die onderwyser sy taal en vak moet gebruik om leerders op te voed indien daar leemtes in hul herkenning van die geskiedenis is. Deelnemer 1 en 2 beweer dat dit oor meer as geskiedenis gaan, naamlik die geskiedenis van Afrikaans ten einde die taalstereotipering van die verlede te neutraliseer:

Deelnemer 1: I think the South African context has relevance, because Afrikaans is so highly politicised, and they explain it in relation to June 16, Sharpville...Political. So, for me, it's exactly that: the story of the relevance, that they do engage... It's not a separate history issue; it's about the history of Afrikaans. If you want to be inclusive, you have to acknowledge that.

Deelnemer 2: That's why I think a lot of white people struggle with the fact that there's more black people who speak Afrikaans as a home language than white people. You would never say Afrikaans is my 'huistaal', because we dissociate. I find myself speaking Afrikaans again for the first time at the University of Pretoria. It kind of goes back to ... because we actively dissociate with it and then also I think that certain pockets of communities might see black people who speak Afrikaans as the working class. It will educate you if you speak English. All these issues are going through my mind as I'm saying this.

Deelnemer 1 bevestig die feit dat bruin sprekers tydens apartheid moedertaalverskuiwing ondergaan het (Engelbrecht, 2003). Die onmiskenbare verskil tussen die uitbeeldings in AOT en die verslag van Esterhuyse (1986) aangaande taalstereotipering, dui daarop dat die sosiolinguistiese werklikheid omtrent Afrikaans volledig in die amptelike kurrikulum gereflekteer word (Esterhuyse, 1986; Engelbrecht, 2003) 


\subsubsection{Konfrontering met die apartheidsverlede.}

Die laaste gesprekstema het gehandel oor die mate waarin die verlede en nasiebou deur die visuele tekste aangespreek word. Verskeie voorbeelde word gegee van die verlede wat "nie vermy word nie" (Deelnemer 5) en van die noodsaaklike bewusmaking van die ervarings van die 'ander helfte' Afrikaners (Deelnemer 6), byvoorbeeld die gedig van Antje Krog (Afrikaans ons taal, 11/12:13) oor 'n Afrikaanse onderwyseres wat tydens die 'struggle' te midde van die onluste probeer skoolhou. Elsa Joubert se roman, Die swerfjare van Poppie Nongena (Afrikaans ons taal, 11/12:11), word as voorbeeld gegee van hoe die (wit) leerders bewus gemaak kan word van die geskiedenis van 'nie-wit' mense. Deelnemer 7 beweer egter (weer) dat daar te veel ruimte in 'n Afrikaanse handboek aan politiek afgestaan word, waarop Deelnemer 1 antwoord:

Dis nie ' $n$ vak op sy eie nie. It's a voice, maar jy gebruik ander vakke om die taal te steun. Die taal is nie iets op sy eie nie, anders as wat die meeste van ons mee opgegroei het. Die tegniese gedeelte van die taal wat eintlik baie min vir ons beteken het, anders as dat jy universiteit toe wou gaan. I think the idea here is to make the language a living language.

\subsection{Vergelyking van die bevindinge}

' $n$ Vergelykende opsomming van die bevindinge van die fokusgroepbesprekings word in tabel 1 aangebied.

Tabel 1: Vergelyking van fokusgroepbesprekingbevindinge

\begin{tabular}{|l|l|}
\hline NIEUW NEDERLANDS & AFRIKAANS ONS TAAL \\
\hline $\begin{array}{l}\text { Voorblad en titel getuig van diversiteit.; verder } \\
\text { min foto's waarin 'anders-as-wit' voorkom }\end{array}$ & $\begin{array}{l}\text { Voorstellings verteenwoordig deurentyd die totale } \\
\text { kultuurspektrum in Suid-Afrika }\end{array}$ \\
\hline $\begin{array}{l}\text { Geen kontekstualisering of didaktiese integrering } \\
\text { van visuele materiaal nie. }\end{array}$ & $\begin{array}{l}\text { UItstekende didaktiese integrering van visuele } \\
\text { materiaal, vrae en aktiwiteite. }\end{array}$ \\
\hline Slegs foto's word gebruik. & $\begin{array}{l}\text { Te veel illustrasies en te min foto's boet } \\
\text { geloofwaardigheid in. }\end{array}$ \\
\hline $\begin{array}{l}\text { Verskille tussen 'ons' en 'hulle' word beklemtoon. } \\
\text { Politieke en religieuse lading in sommige foto's. } \\
\text { Afrikaanssprekendes word beklemtoon }\end{array}$ & $\begin{array}{l}\text { Menseregtekwessies en politieke inhoud word } \\
\text { verwar. }\end{array}$ \\
\hline $\begin{array}{l}\text { Ekstremistiese, karikatuuragtige foto's poog om } \\
\text { te vermaak. }\end{array}$ & Butterscotch-tegniek verdoesel rassensitiwiteit. \\
\hline $\begin{array}{l}\text { Verrassingstegniek deur ongewone situasies wat } \\
\text { van die tipiese Westerse norm afwyk. }\end{array}$ & $\begin{array}{l}\text { Outentiekheid van sekere tekste word } \\
\text { bevraagteken. }\end{array}$ \\
\hline $\begin{array}{l}\text { Paternalistiese uitbeeldings toon agterlikheid en } \\
\text { onderontwikkeldheid buite Nederland. }\end{array}$ & $\begin{array}{l}\text { Geforseerdheid van rolmodelle, asook die indruk } \\
\text { wat geskep word dat almal net Afrikaans praat. }\end{array}$ \\
\hline $\begin{array}{l}\text { Ignorering van die tipiese Nederlandse } \\
\text { diversiteitswerklikheid }\end{array}$ & $\begin{array}{l}\text { Rassensitiwiteit en polarisering in } \\
\text { fokusgroepbespreking. }\end{array}$ \\
\hline $\begin{array}{l}\text { Nederland en Nederlanders. } \\
\text { Die apartheidsverlede word openlik bespreek. }\end{array}$ \\
\hline
\end{tabular}


Die fokusgroepbesprekings het in " $\mathrm{n}$ groot mate die dilemmas en diskrepansies onderliggend aan die sosiale operasionalisering in Nederland en Suid-Afrika geïdentifiseer. Op grond van die fokusgroepbesprekings is die vlak van interkulturaliteit in Afrikaanse handboeke veel hoër as in Nederlandse handboeke. Sensitiewe kwessies (veral rondom politiek en godsdiens) word aangespreek (waarskynlik) weens doelbewuste beleidsinisiatiewe van uitgewers en onderwysdepartemente. So geslaagd is die diversiteitsuitbeelding in die handboekreeks dat ' $n$ anti-rassistiese en utopiese staat (Montgomery, 2005) daardeur gekonstrueer word, wat soms geforseerd voorkom.

In teenstelling hiermee, kom daar in die Nederlandstalige data veel meer teenstrydige kodes voor, byvoorbeeld beskaaf/primitief, ontwikkeld/onontwikkeld, religieus/nie-religieus. Eurosentriese perspektiewe is waarneembaar in die feit dat verskille eerder as ooreenkomste tussen wit en ander Nederlanders beklemtoon word. Strategieë soos ignorering, verkleining van die buitegroep se bydrae en negatiewe eerder as positiewe inligting oor die buitegroep dra by tot die ideologiese voorstellings in die handboekreeks.

\section{Slot}

Daar is min, indien enige ooreenkomste tussen die dogterstale Nederlands en Afrikaans se hantering van diversiteit in moedertaal-taalhandboeke. Die visuele materiaal in die boeke suggereer dat Afrikaans inderdaad sy koloniale mentaliteit ontgroei het, maar dat Eurosentriese perspektiewe nog ongehinderd in Nederlandse handboeke figureer.

\section{VERWYSINGS}

Allochtoon. Sa. Sl. All Experts Encyclopedia: [Aanlyn beskikbaar]: http://experts.about.com/e/a/al/ Allochtoon.htm. Toegangsdatum: 2006-8-29.

Apple, M.W. \& Christian-Smith, L.K. (eds.). 1991. The politics of the textbook. New York: Routledge Roland.

Apple, M.W. 1990. Ideology and curriculum. New York: Routledge.

Auerbach, F.E. 1965. The power of prejudice in South African education. Kaapstad: A.A. Balkema.

Babbie, E. \& Mouton, J.A. 2001. Social research. Cape Town: Oxford.

Baldwin, E., Longhurst, B., McCracken, S., Ogborn, M. \& Smith, G. 2004. Introducing cultural studies. London: Pearson Education.

Botman, M. Jouwe, N. \& Wekker, G. 2001. Caleidoschopiesche visies: De zwarte, migranten en vluchtelingen-vrouwenbeweging in Nederland. Amsterdam: Koninklijke Instituut voor de Tropen.

Bourdillon, H. (ed.). 1992. History and social studies - methodologies of textbook analysis. Report of the Educational Research Workshop, Braunschweig, Germany, 11-14 September 1990. Amsterdam: Swets \& Zeitlinger.

Castelli, L., Vanzetto, K., Sherman, S. \& Arcuri, L. 2001. The explicit and implicit perception of in-group members who use stereotypes: Blatant rejection but subtle conformity. Journal of Experimental Social Psychology, 37: 419-426.

Creswell, J.W. 1994. Research design - qualitative \& quantitative approaches. California: Sage.

Dean, E., Hartmann, P. \& Katzen, M. 1983. History in black and white: An analysis of South African school history textbooks. Belgium: Unesco. 
De Figueiredo, J. P. \& Elkins, Z. 2003. Are patriots bigots? An inquiry into the vices of in-group pride. American Journal of Political Science, 47(1): 171-191.

De Jongh, J. 1995. Beeldvorming, de derde wereld en het milieu: Een alternatief. Amsterdam: PAREL.

Engelbrecht, A. 2003. Who moved the textbook ... ? A case study describing how ideological change in South Africa manifested itself in terms of racial representation in a transitional Afrikaans language textbook series. Unpublished MEd Dissertation. Pretoria: University of Pretoria.

Engelbrecht, A. 2008. The impact of role reversal in representational practice in history textbooks after apartheid. South African Journal of Education, 28(4):519-541.

Engelbrecht, A. 2009. Kultuurstereotipering in moedertaal-taalhandboeke in Afrikaanse, Nederlandse en Vlaamse gemeenskappe. Ongepubliseerde PhD-verhandeling. Pretoria: Universiteit van Pretoria.

Esterhuyse, J. 1986. Taalapartheid en skoolafrikaans. Emmarentia: Taurus.

Giroux, H.A. 1995. National identity and the politics of multi-culturalism. College Literature, 22(2): 687-697.

Greaney, V. 2004. Textbooks and reading materials: Do they promote respect for diversity, social cohesion and peace? Paper read at the READ SEMINAR. Johannesburg, South Africa, February 12.

Hagendoorn, L. 1986. Cultuurconflict en vooroordeel: Essays over de waarneming en betekenis van cultuurverschillen. Nijmegen: Samson.

Hall, S. (ed.). 1997. Representation. Cultural representations and signifying practices. Londen: Sage.

Homan, H.D.I. (ed.). 2003. DIMPLE. Dissemination and implementation of help desks for intercultural Learning Materials. Utrecht: PAREL.

Höpken, W. 2006. Textbooks and conflicts: Experiences from the work of the George Eckert Institute for International Textbook Research. Paper read at the World Bank, 24-26 March, Washington, D.C.

Jansen, J.D. 1989. Curriculum reconstruction in post-Colonial Africa: A review of the literature. International Journal of Education Development, 9(3): 219-231.

Kaomea, J. 2000. A curriculum of Aloha? Colonialism and tourism in Hawai's elementary textbooks. Curriculum Inquiry, 30(3):337-342.

King, R. \& Morrisey, M. 1988. The portrayal of race in contemporary Caribbean textbooks. Paper read at the Caribbean Studies Association Conference Point-a-Pitre, Guadeloupe, 25-27 May.

Kirkness, V. 1977. Prejudice about Indians in textbooks. Journal of Reading, 20: 595-600.

Kusendila, B. 2003. Language education and national identity - a comparative study of Flemish and Afrikaans L1 instruction materials since 2000. Unpublished MEd Dissertation. Cape Town: University of Cape Town Press.

Ledic, J. 2000. Croatia above all: Values/messages in the Croatian elementary school curriculum. Paper read at the European Conference on Educational Research, Edinburgh, 20-23 September.

Marsden, William, E. 2001. The school textbook: Geography, history and social studies. London: Woburn Press.

McCall, J. 2005. Books and the nation: Aspects of publishing and national identity. Paper read at the University of Pretoria, 6 September.

McKinney, C. 2005. Textbooks for diverse learners. A critical analysis of learning material used in South African schools. Pretoria: Human Sciences Research Council.

McDiarmid, G. \& Pratt, D. 1971. Teaching prejudice. A content analysis of school studies textbooks authorized for use in Ontario. Ontario: The Ontario Institute for Studies in Education.

Mok, R.J.M. \& Reinsch, P. 1996. Kieskleurig: Handleiding intercultureel lesmateriaal. Utrecht: PAREL. 
Montgomery, K. 2005. Imagining the anti-racist state: Representations of racism in Canadian history textbooks. Discourse: Studies in the Cultural Politics of Education, 26(4):427-442.

Mouton, J.A. 2001. How to succeed in your master's and doctoral studies. Pretoria: Van Schaik.

Nele, K. 1996. Beeldvorming bij kinderen over de derde wêreld: Effect onderzoek, toegepast op een Zaïreinleef-project voor kinderen uit de derde graad van het lager onderwijs. Gent: Universiteit Gent.

Nganda, I. 1996. A study of ethnic stereotypes in the Ugandan basic textbooks for primary school English and social studies. Germany: Bayreuth University.

Paton, L. \& Deverell, J. 1974. Prejudice in social studies' textbooks: A content analysis of social studies' textbooks used in Saskatchewan schools. Saskatoon: Modern Press.

Paul Schnabel. 2009. [Aanlyn beskikbaar]: http://en.wikipedia.org/wiki/ Paul_Schnabel. [Toegangsdatum]: 2007/03/15.

Perkins, T. 2003. Rethinking stereotypes. Reader: Media, cultuur en maatschappij studies. Utrecht: Utrecht Universiteit.

Radio Sonder Grense - nuusberig oor handboeke: 8 Mei 2006.

Rice, N. 2005. Guardians of tradition: Presentations of inclusion in three introductory special education textbooks. International Journal of Inclusive Education, 9(4): 405-429.

Roberts-Schweitzer, E. (ed.). 2006. Promoting social cohesion through education. Washington D.C.: World Bank.

Shadid, W.A.R. 1994. Beeldvorming: De verborgen dimensie bij interculturele communicatie: Tilburg: Tilburg University Press.

Sierens, S. 2007. Diversiteit in leren, leren in diversiteit: Burgerschapvorming en gelijke leerkansen in een pluforme samenleving. Gent: Steunpunt Diversiteit en Leren.

Smelink, A. 1999. Effectief beeldvormen: Theorie, analyse en praktijk van beeldvormingsprocessen. Assen: Van Gorcum.

Stewart, M.S. 1950. Prejudice in textbooks. Report of the Committee on the Study of Teaching Materials in Intergroup Relations. Washington DC: Public Affairs Committee.

Van den Bergh, H. \& Reinsch, P. 1983. Racisme in schoolboeken. Amsterdam: Uitgeverij SUA.

Webb, V.N. 1992. Afrikaans na apartheid. Pretoria: Van Schaik.

Wekker, G. Persoonlike gesprek, 23 Julie 2006, Pretoria.

\section{OOR DIE SKRYWER}

Alta Engelbrecht

Departement van Geesteswetenskaplike Opvoeding

Fakulteit Opvoedkunde

Universiteit van Pretoria

Groenkloofkampus

Pretoria

0002

E-pos: a.engelbrecht@gk.up.ac.za 